\title{
Preparation and Properties of [Monoiodotyrosine]-Insulin
}

\author{
By D. A. BIHLER* and J. W. S. MORRIS $\dagger$ \\ Department of Pathology, California College of Medicine, University of California Irvine, \\ Irvine, Calif. 92664, U.S.A.
}

(Received 18 August 1972)

Iodinated insulins have found widespread use in radioimmunoassay and as biological tracers (Haugaard et al., 1954; Berson et al., 1956; Welsh et al., 1956; Edelman \& Schwartz, 1966; Tomasi et al., 1967). Consequently, biological and immunological properties of iodinated insulins have been the subject of considerable investigation (De Zoeten \& Van Strik, 1961; Izzo et al., 1964; Rosa et al., 1967; Glover et al., 1967; Arquilla et al., 1968; Brunfeldt et al., 1968; Massaglia et al., 1969; Freychet et al., 1971b; Garratt et al., 1972). Previous studies have been hampered by the lack of adequate separation techniques for the preparation of iodinated insulins. We present a method of preparation and purification of a biologically active mono-iodinated insulin. This work was presented in part at the 7th. Congress of the International Diabetes Federation, Buenos Aires, Argentina, on 23-28 August 1970.

Iodination of insulin was performed by a method based on work of Mayberry et al. (1964) on the iodination of tyrosine derivatives. In a typical preparation $130 \mu \mathrm{mol}$ (1.5 equiv.) of $I_{2}$ in $2 \mathrm{ml}$ of ethanol was allowed to exchange with $500 \mu \mathrm{Ci}$ of carrier-free $\mathrm{Na}^{125} \mathrm{I}$ (New England Nuclear Corp., Boston, Mass., U.S.A.). This solution was then added to $87 \mu \mathrm{mol}$ $(500 \mathrm{mg})$ of bovine insulin (Elanco no. 1CB98W; Eli Lilly and Co., Indianapolis, Ind., U.S.A.). The reaction was carried out in $0.11 \mathrm{M}$-sodium phosphate buffer, $\mathrm{pH} 7.4$, at an insulin concentration of $2.5 \mathrm{mg} /$ $\mathrm{ml}$ at $23^{\circ} \mathrm{C}$. The iodinating mixture was added to the magnetically stirred insulin solution in $100 \mu$ l portions over a $2 \mathrm{~min}$ interval. The stirring was continued for $30 \mathrm{~min}$. In all preparations $47-50 \%$ of the radioactivity was precipitable in $1 \mathrm{M}$-trichloroacetic acid, indicating that the reaction was $94-100 \%$ complete. The $\mathrm{pH}$ was adjusted to 5.2 , and the resulting precipitate was collected by centrifugation and washed three times with water.

To separate the iodinated insulin derivatives advantage was taken of the fall of the phenolic $\mathrm{p} K$ from 10.1 to 8.6 that accompanies introduction of an iodine atom in the ortho position of tyrosine

\footnotetext{
* Present address: Department of Environmental Interactions, California College of Medicine, University of California Irvine, Irvine, Calif. 92664, U.S.A.

† Present address: California College of Medicine, University of California Irvine, Irvine, Calif. 92664, U.S.A.
}

(Sokolovsky et al., 1967). At pH8.6 [monoiodotyrosine]-insulin should have a charge difference of $-\frac{1}{2}$ relative to insulin. A further fall in phenolic $\mathrm{p} K$ from 8.6 to 6.8 accompanies the formation of 3,5-diiodotyrosine. Introduction of a second iodine atom into either an iodotyrosine residue or a tyrosine residue should result in an additional charge difference at $\mathrm{pH} 8.6$ of $-\frac{1}{2}$ relative to insulin. Therefore separation of iodinated insulins based on net charge at pH 8.6 should result in fractions of the same degree of iodination. Accordingly, the reaction mixture was separated on a column $(4 \mathrm{~cm} \times 100 \mathrm{~cm})$ of DEAESephadex A-25 at $4^{\circ} \mathrm{C}$. The column was equilibrated with a buffer containing $0.14 \mathrm{M}-\mathrm{NaCl}, 0.01 \mathrm{M}$-tris$\mathrm{HCl}, \mathrm{pH} 8.60 \pm 0.02$, and $7 \mathrm{M}$-urea. Elution at $60 \mathrm{ml} / \mathrm{h}$ was performed with a salt gradient $(0.14-0.4 \mathrm{M}-\mathrm{NaCl})$ in the tris-urea buffer. The $E_{276}$ and radioactivity (Packard model 3002 scintillation spectrometer) of each fraction $(20 \mathrm{ml})$ was determined (Fig. 1a). Corresponding peaks were promptly pooled and dialysed at $4^{\circ} \mathrm{C}$ against $0.01 \mathrm{M}$-ammonium formate buffer, pH5.2. The resulting precipitates were collected by centrifugation, washed with water and freeze-dried.

The specific radioactivities [c.p.m./ $E_{276}$ unit (in $0.01 \mathrm{M}-\mathrm{HCl}$ )] of the peaks I-IV were in the proportions 1.24:2.36:3.00:3.95. Neutron-activation analysis revealed iodine contents of $3.1 \pm 0.3,4.4 \pm 0.2$, $6.6 \pm 0.4$ and $9.1 \pm 0.5 \%$ for fractions I-IV respectively. The theoretical values for mono-, di-, tri- and tetra-iodoinsulin are 2.15, 4.17, 6.13 and $8.02 \%$.

Peak I from a separation similar to that shown in Fig. 1(a) was rechromatographed to obtain purified [monoiodotyrosine]-insulin (Fig. 1b). Two distinct fractions were obtained. The first fraction $\left(F_{1}\right)$, evidently unchanged insulin, crystallized in high yield from $0.01 \mathrm{M}$-sodium acetate- $1 \mathrm{~mm}-\mathrm{ZnSO}_{4}-5 \%$ $(\mathrm{w} / \mathrm{v}) \mathrm{NaCl}, \mathrm{pH}$ 5.9. The second fraction $\left(\mathrm{F}_{\mathrm{II}}\right)$, [monoiodotyrosine]-insulin, did not crystallize under these conditions. The absorption spectra of fraction $F_{\text {II }}$ were fully consistent with the presence of 1 equivalent of L-3-iodotyrosine. A batch of [monoiodotyrosine]-insulin, prepared as described above, had an iodine content of $2.05 \pm 0.15 \%$ when dried to constant weight.

Oxidative sulphitolysis (Bromer et al., 1967) followed by separation on Dowex 50 (Morris et al., 1970) revealed that $95 \%$ of the radioactivity was present on the A chain. Chymotryptic hydrolysis (Aoyama et al., 1965) demonstrated that the distribution of

Vol. 130 

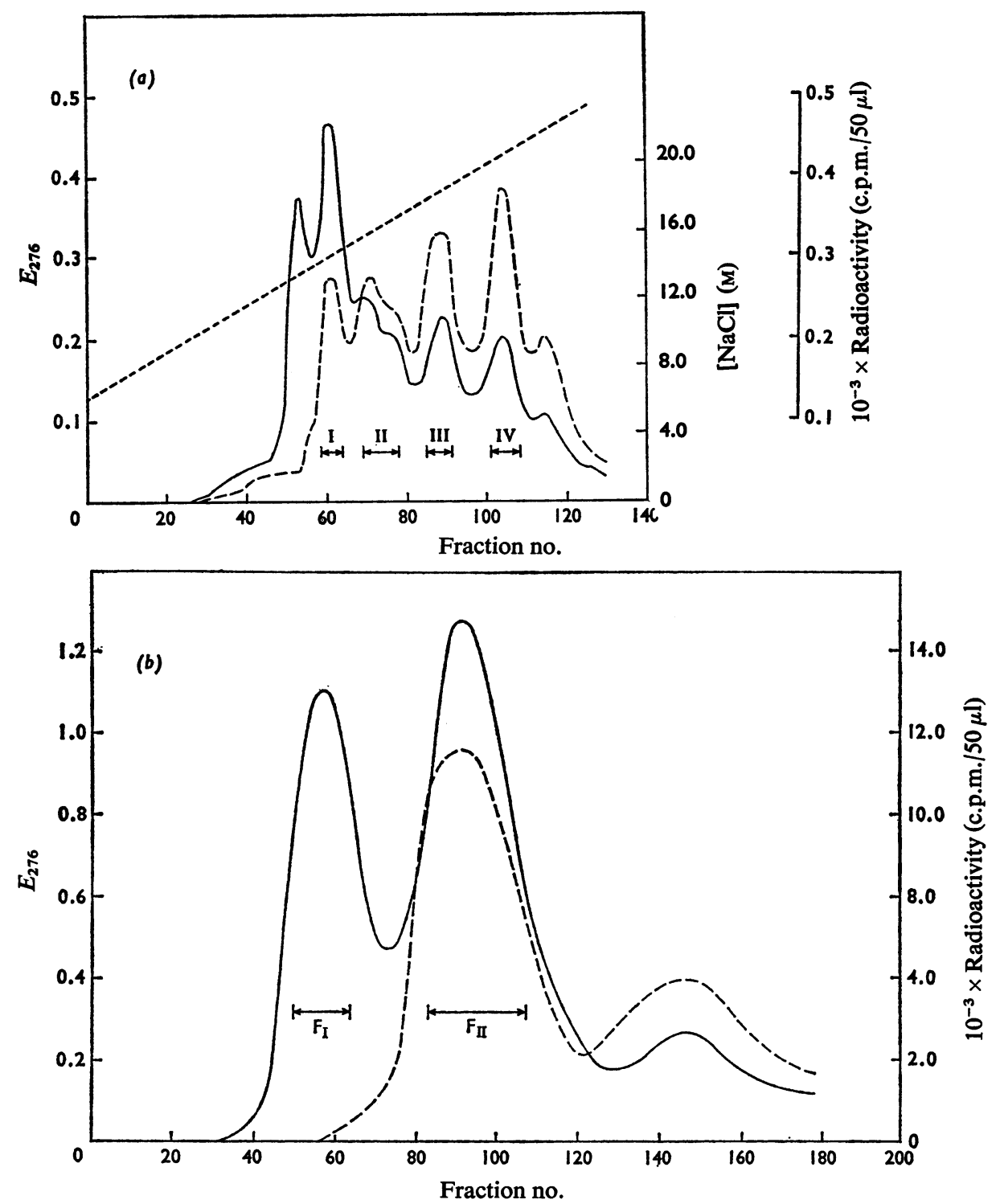

Fig. 1. Chromatography of insulin and derivatives

(a) Ion-exchange chromatography of the iodinated reaction mixture. The iodinated reaction mixture was separated on a column $(4 \mathrm{~cm} \times 100 \mathrm{~cm})$ of DEAE-Sephadex A-25 at $4^{\circ} \mathrm{C}$. The column was equilibrated with a buffer containing $0.14 \mathrm{M}-\mathrm{NaCl}, 0.01 \mathrm{M}$-tris $-\mathrm{HCl}, \mathrm{pH} 8.60 \pm 0.02$, and $7 \mathrm{M}$-urea. Elution at $60 \mathrm{ml} / \mathrm{h}$ was performed with a salt gradient (----, 0.14-0.4 $\mathrm{M}-\mathrm{NaCl})$ in the tris-urea buffer and $20 \mathrm{ml}$ fractions were collected. (b) Rechromatography of iodinated insulin. [Monoiodotyrosine]-insulin was further purified on a column $(1.5 \mathrm{~cm} \times 60 \mathrm{~cm})$ of DEAE-Sephadex A-25 at $4^{\circ} \mathrm{C}$. The column was equilibrated with a buffer containing $0.10 \mathrm{M}-\mathrm{NaCl}, 0.01 \mathrm{M}$-tris$\mathrm{HCl}, \mathrm{pH} 8.60 \pm 0.02$, and $7 \mathrm{M}$-urea. Elution at $40 \mathrm{ml} / \mathrm{h}$ was performed with the same buffer at constant ionic strength and $10 \mathrm{ml}$ fractions were collected. -,$E_{276} ;----$, radioactivity.

radioactivity between tyrosine residues $\mathrm{A} 19$ and $\mathrm{A} 14$ was 1:1. Gel filtration (on Sephadex G-50) of the monosubstituted derivative was performed in $7 \mathrm{M}$ urea-0.01 $\mathrm{M}-\mathrm{NaCl}-0.05 \mathrm{M}$-tris- $\mathrm{HCl}$, pH7.5 (Boesel
\& Carpenter, 1970). Results gave no indication of intermolecular cross-linking, as has been noted in unseparated reaction mixtures of iodinated insulins (Csorba \& Gattner, 1970). 


\section{Table 1. Biological and immunological activities of insulin and derivatives}

Biological activity was measured by the mouse convulsion assay (Young \& Louis, 1947), and is expressed as the mean \pm the $95 \%$ confidence interval for the numbers of mice in parentheses. Immunological activity was measured by passive immune haemolysis inhibition (Arquilla, 1972).

$\begin{array}{lcc}\text { Insulin or derivative } & \begin{array}{c}\text { Biological activity } \\ \text { (i.u./mg) }\end{array} & \begin{array}{c}\text { activity } \\ (\%)\end{array} \\ \text { Unchanged insulin }\left(F_{\mathbf{l}}\right) & 24.1 \pm 4.0(150) & 100 \\ \text { [Monoiodotyrosine]-insulin }\left(F_{\mathrm{II}}\right) & 16.8 \pm 2.8(150) & 6 \\ \text { [Mono-3-nitrotyrosine]-insulin } & 12.8 \pm 2.7(270) & 4^{*} \\ \text { [Di-3-nitrotyrosine]-insulin } & 5.3 \pm 0.8(210) & 9^{*}\end{array}$

* Morris et al. (1970).

The biological activities of unchanged insulin $\left(F_{I}\right)$, [monoiodotyrosine]-insulin $\left(\mathrm{F}_{\mathrm{II}}\right)$ and [mono- and di3-nitrotyrosine]-insulins (Morris et al., 1970) were measured by the mouse convulsion assay (Table 1). The results presented are based on weight, and have not been corrected for water content. The biological activity of unchanged insulin $\left(F_{1}\right)$ compared favourably with the biological activity of the crystalline starting material (26.0i.u./mg). Previous determinations (Morris et al., 1970) of the biological activity of [mono- and di-3-nitrotyrosine]-insulin, based on a blood-sugar depression assay, differ significantly from results of the mouse convulsion assay presented here.

The ability of [monoiodotyrosine]-insulin, [mono3-nitrotyrosine]-insulin, [di-3-nitrotyrosine]-insulin and unchanged insulin to combine with purified guinea-pig anti-insulin antibodies was measured by passive immune haemolysis inhibition (Arquilla, 1972) (Table 1).

We have prepared and characterized [monoiodotyrosine]-insulin, which was found to be a mixture of the isomers with tyrosine residues A14 and A19 substituted. Results on the localization of the sites of substitution are in accord with results based on unseparated iodinated insulins (Massaglia et al., 1969; De Zoeten \& Havinga, 1961). This insulin derivative is biologically active, in agreement with reports on heterogeneous iodinated insulin preparations characterized by an average degree of substitution (Rosa et al., 1967). Our results on biological activity substantiate recent findings on the biological activity of purified [monoiodotyrosine]insulin (Freychet et al., 1971a). Immunological characteristics as measured by passive immune haemolysis inhibition correspond well with results obtained in this laboratory on [3-nitrotyrosine]insulins, which also possess predominant A-chain tyrosine residue substitution. In addition, the [monoiodotyrosine]-insulin was found to have a maximum insulin contamination of $6 \%$, as indicated by its immunological activity.
Our results indicate that substitution of A-chain tyrosine residues has a marked effect on immunological activity and a relatively minor effect on biological activity. In this regard, it can be expected that mono[ ${ }^{125}$ I] $]$ iodo-insulin should be a reliable competitor in a 'receptor site' assay. This view is supported by the results of Freychet et al. (1971b), which demonstrate that only biologically active insulin derivatives could effectively displace ${ }^{125}$ I-labelled insulin bound to liver or fat-cells. In contradistinction, poor correlation was found between the activity in the radioimmunoassay and the biological activity of the insulin derivatives tested.

This investigation was supported by Grant 9-445140. 45520 from the Southern California Diabetes Association. We thank Dr. William W. Bromer of the Lilly Research Laboratories, Indianapolis, Ind., U.S.A. for determining the biological activities of these insulin derivatives, and Dr. Vincent P. Guinn of the Department of Chemistry, University of California Irvine, for the neutron-activation analyses.

Aoyama, M., Kurihara, K. \& Shibata, K. (1965) Biochim. Biophys. Acta 107, 257-265

Arquilla, E. R. (1972) Methods Immunol. Immunochem. 4 , in the press

Arquilla, E. R., Ooms, H. \& Mercola, D. A. (1968) J. Clin. Invest. 47, 474-487

Berson, S. A., Yalow, R. S., Bauman, A., Rothschild, M. A. \& Newerly, K. (1956) J. Clin. Invest. 35, 170 190

Boesel, R. W. \& Carpenter, F. H. (1970) Biochem. Biophys. Res. Commun. 38, 678-691

Bromer, W. W., Sheehan, S. K., Berns, A. W. \& Arquilla, E. R. (1967) Biochemistry 6, 2378-2388

Brunfeldt, K., Hansen, B. A. \& Jorgensen, K. R. (1968) Acta Endocrinol. (Copenhagen) 57, 307-329

Csorba, T. R. \& Gattner, H. G. (1970) Horm. Metab. Res. 2, 305-306

De Zoeten, L. W. \& Havinga, E. (1961) Rec. Trav. Chim. Pays-Bas 80, 917-926

De Zoeten, L. W. \& Van Strik, R. (1961) Rec. Trav. Chim. Pays-Bas 80, 917-926 
Edelman, P. M. \& Schwartz, I. L. (1966) Amer.J. Med.40, 695-708

Freychet, P., Roth, J. \& Neville, D. M., Jr. (1971a) Biochem. Biophys. Res. Commun. 43, 400-408

Freychet, P., Roth, J. \& Neville, D. M., Jr. (1971b) Proc. Nat. Acad. Sci. U.S. 68, 1833-1837

Garratt, C. J., Harrison, D. M. \& Wicks, M. (1972) Biochem. J. 126, 123-131

Glover, J. S., Salter, D. N. \& Shepherd, B. P. (1967) Biochem. J. 103, 120-128

Haugaard, N., Haugaard, E. S. \& Stadie, W. C. (1954) J. Biol. Chem. 211, 289-295

Izzo, J. L., Bale, W. F., Izzo, M. J. \& Roncone, A. (1964) J. Biol. Chem. 239, 3743-3748
Massaglia, A., Rosa, U., Rialdi, G. \& Rossi, C. A. (1969) Biochem. J. 115, 11-18

Mayberry, W. E., Roll, J. E. \& Bertoli, D. (1964) J. Amer. Chem. Soc. 86, 5302-5307

Morris, J. W. S., Mercola, D. A. \& Arquilla, E. R. (1970) Biochemistry 9, 3930-3937

Rosa, U., Massaglia, A., Pennisi, F., Cozzani, I. \& Rossi, C. A. (1967) Biochem. J. 103, 407-412

Sokolovsky, M., Riordan, J. F. \& Vallee, B. L. (1967) Biochem. Biophys. Res. Commun. 27, 20-25

Tomasi, T., Sledy, D., Wales, J. K. \& Recant, L. (1967) Proc. Soc. Exp. Biol. Med. 126, 315-317

Welsch, G. W., Henley, E. D., Williams, P. H. \& Cox, R. W. (1956) Amer. J. Med. 21, 324-338 